\title{
EFFECTS OF CAFFEINE AND PROCAINE ON THE MEMBRANE AND MECHANICAL PROPERTIES OF THE SMOOTH MUSCLE CELLS OF THE RABBIT MAIN PULMONARY ARTERY
}

\author{
Yushi Ito, Hikaru Suzuki, and Hirosi KurIYAma \\ Department of Pharmacology, Faculty of Medicine, Kyushu University, \\ Fukuoka, 812 Japan
}

\begin{abstract}
Effects of caffeine and procaine on the membrane and mechanical properties of the smooth muscles of the rabbit main pulmonary artery were investigated using microelectrode and voltage clamp methods. Caffeine $(>0.5 \mathrm{~mm}$ ) depolarized the membrane and increased ionic conductance. On the other hand, procaine $(>2.5 \mathrm{~mm})$ depolarized the membrane, generated spikes and reduced the ionic conductance of the membrane. When depolarization-contraction relations were observed, the threshold depolarization to evoke contraction and the amplitude of the contraction were not affected by $5 \mathrm{~mm}$ procaine. However, the mechanical threshold was raised and the mechanical response was suppressed by treatment with 5 and $10 \mathrm{~mm}$ caffeine or $10 \mathrm{~mm}$ procaine. Procaine and caffeine accelerated the depletion of $\mathrm{Ca}^{++}$from the stored sites in Ca-free (EGTA) solution, and suppressed the mechanical responses induced by chemical stimulation. Caffeine and procaine suppressed the increase in ionic conductance and depolarization produced by noradrenaline or prostaglandin $F_{2 \alpha}$. Caffeine also suppressed the mechanical response induced by the above agents. Procaine suppressed the noradrenaline induced contraction, but accelerated the prostaglandin $F_{2 \alpha}$ induced contraction. From the above results, it is concluded that caffeine and procaine act not only on Ca-stored sites in the cell but also on the surface membrane. The actions of these agents were not competitive with each other, thus suggesting that the properties of the internal membrane structures, which is assumed to be a main Ca-storage site, are not exactly the same as those in striated muscles.
\end{abstract}

Received for publication May 13, 1977

伊東祐之，鈴木 光，栗山 熙 
WEBER (1968) demonstrated the site of caffeine action in fragmented sarcoplasmic reticulum (SR) excised from skeletal muscle and also showed that $\mathrm{Ca}^{++}$ is required for caffeine action. ENDO et al. (1970) further investigated the caffeine action using frog skinned muscle fiber and concluded that the caffeine action on the SR was a facilitation of the Ca-releasing mechanism but not a reduction of the capacity of the SR to accumulate $\mathrm{Ca}^{++}$. Moreover, the mechanism of caffeine action was recently explained as labilization of the Ca-induced $\mathrm{Ca}$ release mechanism rather than augmentation of Ca release from the SR (ENDO, 1975; EBASHI, 1976). It was also shown in skeletal muscle that the mode of procaine action could be explained as a stabilization of the Ca-induced $\mathrm{Ca}$ release mechanism (Ford and PODOLSKY, 1972).

Even the role of the $\mathrm{Ca}$-induced $\mathrm{Ca}$ release mechanism under physiological conditions is a minor or negligible factor compared with that induced by electric potential across the SR membrane. The actions of procaine and caffeine provided quite a bit of information to understanding the excitation-contraction coupling mechanism in skeletal muscle as crucial tools for clarifying the physiological function.

On the other hand, the action of these chemical agents on visceral smooth muscle have not yet been fully investigated and seem to be more complicated than the action of those on skeletal muscle. For example, caffeine acted on both sarcoplasmic membrane and contractile phenomena. Furthermore, the responses of the membrane to caffeine differed in different regions of the alimentary canal in either an excitatory or inhibitory direction. Moreover, the responses to caffeine in the longitudinal and circular muscle of tissue excited from the same region of the alimentary canal also differed (Iто et al., 1973; KuRiYama et al., 1975).

Procaine action on the rnembrane and contractile phenomena were recorded from various visceral muscles. However, in contrast to caffeine action, procaine consistently showed excitatory action on the visceral muscle membranes, i.e., it suppressed $\mathrm{K}$ conductance, depolarized the membrane, and enhanced spike frequency and spike amplitude. Moreover, the spike was evoked by the outward current pulse from electrically quiescent muscles. In spite of the excitatory action on the membrane, the mechanical response evoked by either depolarization or chemical substances was suppressed in guinea-pig taenia coli (BüLBRING and KuriYAMA, 1973), guinea-pig urinary bladder (KuRIHARA, 1975), sheep carotid artery (KeAting, 1975), and rabbit pulmonary artery (CASTEELs et al., 1977a).

Morphological and functional specificities of mammalian visceral muscles were elucidated in comparison with those of skeletal muscle (BÜLBRING et al., 1970; Bülbring and NeEdHaM, 1973; Bülbring and SHuba, 1976; WorCEl and VASSORT, 1976). However, study of the excitation-contraction coupling, or pharmaco-contraction coupling mechanism (SomLyo and SomLYo, 1968) in relation to the role of $\mathrm{Ca}^{++}$in visceral smooth muscle is still far from satisfactory.

The present experiments were intended to investigate the roles of $\mathrm{Ca}^{++}$in 
relation to modulators of $\mathrm{Ca}^{++}$mobilization, caffeine and procaine, on the membrane and mechanical properties of vascular smooth muscles. As an example of vascular muscle, the rabbit pulmonary artery was used because this muscle tissue did not generate a spike. Therefore, a factor of the mechanical response by early Ca-inward current could be neglected, and various parameters of the membrane have already been reported (CASTEELS et al., 1977 a,b; Iто et al., 1977).

\section{METHODS}

Albino rabbits of either sex, weighing 2.5 to $3.0 \mathrm{~kg}$, were stunned and bled. The main pulmonary artery was excised and freed of connective tissue under a dissecting microscope. The tissues were cut circularly at a width of 2.0 to $2.5 \mathrm{~mm}$ and a length of about $10 \mathrm{~mm}$ for the studies of single cell properties and for isometric tension recording. The tissues were also cut circularly at a width of $1.0 \mathrm{~mm}$ and a length of about $10 \mathrm{~mm}$ for the double sucrose gap experiments.

For the recording of membrane potentials of single cells, conventional microelectrodes filled with $3 \mathrm{M} \mathrm{KCl}$ were used. They were inserted from the outer surface of the preparation. In order to measure the changes in membrane resistance of the smooth muscle tissue, the partition stimulating method was used as described by ABE and TOMITA (1968). The chamber for the microelectrode method had a volume of $2 \mathrm{ml}$ and was perfused at a rate of $3 \mathrm{ml} / \mathrm{min}$ at a temperature $35-36^{\circ} \mathrm{C}$.

For recording the membrane potential of the cells, the double sucrose gap method was used. The chamber in which the preparation was mounted was a modification of that used originally by ROUGIER et al. (1969), consisting of five Lucite compartments separated by four diaphragms with holes in the center. Two of the diaphragms between the central and terminal compartments were each composed of three close fitting, slotted plates utilized for fixing the preparation. The other two were rubber membranes and the muscle bundle was pulled through the tight fitting holes and connected to a strain gage for tension measurement. Therefore, the measured tension was not strictly isometric tension. The central compartment $0.5 \mathrm{~mm}$ in width was perfused with Krebs solution or test solution. The intermediate compartments, each $1 \mathrm{~mm}$ in width, were perfused with isotonic sucrose solution. The terminal compartments were relatively large pools, filled with isotonic $\mathrm{KCl}$ solution (Goto et al., 1974). The circuit used for the voltageclamp experiments was essentially similar to that described by ANDERSON (1969). A high-voltage operational amplifier of the feed-back circuit (ОнвA et al., 1975).

Krebs solution (BüLbRING and KURIYAMA, 1963) was used as the normal solution and had the following composition (mM); $\mathrm{Na}^{+}, 137.4 ; \mathrm{K}^{+}, 5.9 ; \mathrm{Mg}^{++}$, $1.2 ; \mathrm{Ca}^{++}, 2.5 ; \mathrm{Cl}^{-}, 134.0 ; \mathrm{H}_{2} \mathrm{PO}_{4}^{-}, 1.2 ; \mathrm{HCO}_{3}{ }^{-}, 15.5$ and glucose 11.5. The solution was aerated with $97 \% \mathrm{O}_{2}$ and $3 \% \mathrm{CO}_{2}$, and its $\mathrm{pH}$ was maintained at 7.2 and 7.3. Isotonic K-Krebs solution was prepared by replacing $\mathrm{NaCl}$ and $\mathrm{NaHCO}_{3}$ with equivalent amounts of $\mathrm{KCl}$ and $\mathrm{KHCO}_{3} .118 \mathrm{~mm}$ K-Krebs 
solution (hereafter called excess $\mathrm{K}^{+}$) was prepared by replacing $\mathrm{NaCl}$ with equivalent amounts of $\mathrm{KCl}$. A Ca-free solution was prepared by removing $\mathrm{CaCl}_{2}$ from the Krebs solution and by adding $0.1 \mathrm{~mm}$ ethylene glycol bis ( $\beta$-aminoethyl ether)-N, $N^{\prime}$-tetraacetic acid (EGTA). The following drugs were used at concentrations described in the results; acetylcholine- $\mathrm{Cl}(\mathrm{ACh})$, noradrenaline- $\mathrm{HCl}$ (Norad), Procaine-Cl, Caffeine, and Prostaglandin $\mathrm{F}_{2 \alpha}\left(\mathrm{PGF}_{2 \alpha}\right.$, Ono Pharma Co. Ltd.).

\section{RESULTS}

Effects of caffeine and procaine on membrane properties

The membrane potential of smooth muscle cells of the main pulmonary artery was $-57.4 \pm 2.4 \mathrm{mV}(n=131)$. Neither spontaneous activity nor fluctuation of the membrane potential was recorded. Figure 1 shows the effects of various

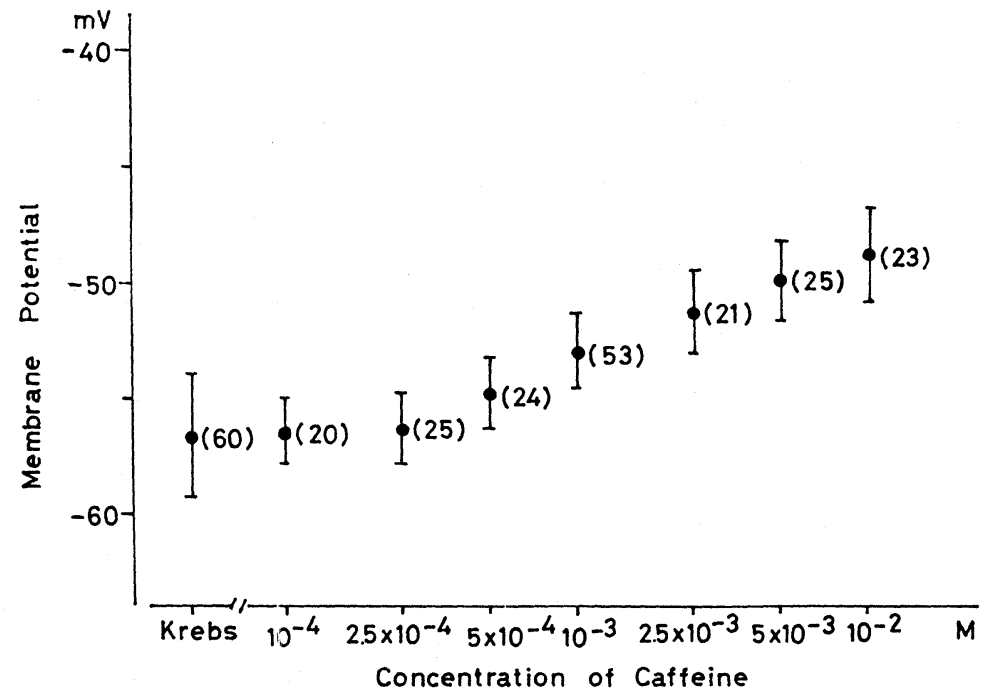

Fig. 1. Effects of caffeine $\left(10^{-4}-10^{-2} \mathrm{M}\right)$ on membrane potential. Vertical bars indicate $2 \times$ S.D.

concentrations of caffeine $(0.1-10 \mathrm{~mm})$ on the membrane potential. When the concentration of caffeine was increased, more than $0.5 \mathrm{mM}$ the membrane was depolarized $(10 \mathrm{~mm} ;-48.2 \pm 2.8 \mathrm{mV}(n=23))$. During the depolarization, the relative membrane resistance obtained from the reduction in amplitude of the electrotonic potential compared with that obtained in Krebs solution decreased. No spike was evoked during depolarization. Figure 2 shows the effects of various concentrations of procaine $(0.1-10 \mathrm{mM})$ on the membrane potential. When the concentration of procaine was increased more than $2.5 \mathrm{~mm}$, the membrane depolarized $(10 \mathrm{mM} ;-53.2 \pm 2.5 \mathrm{mV}(n=24))$. The amount of depolarization pro- 


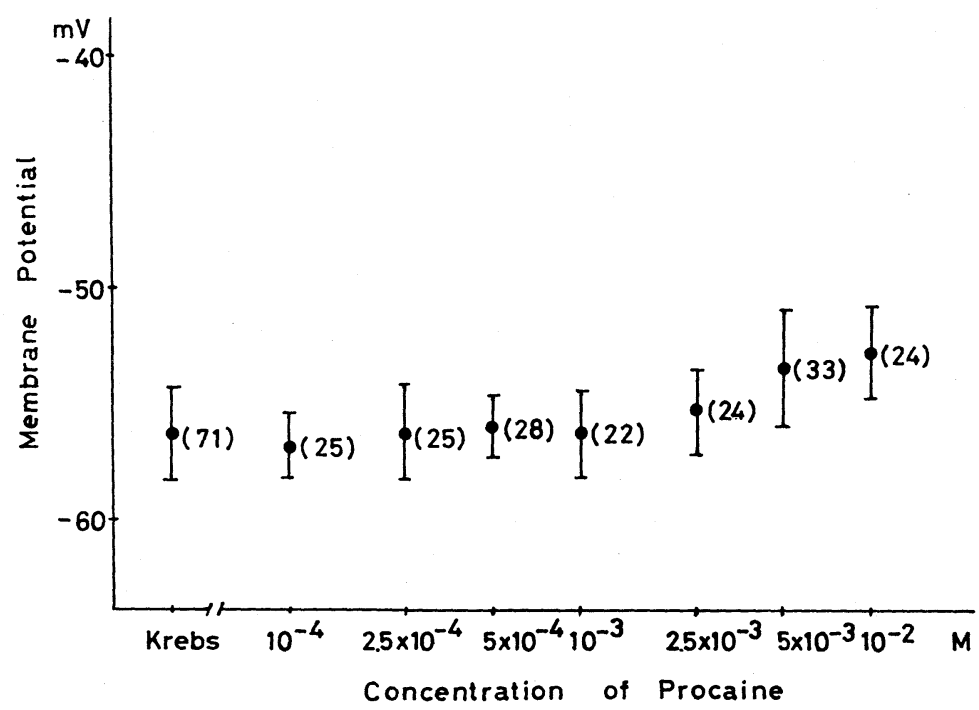

Fig. 2. Effects of procaine $\left(10^{-4}-10^{-2} \mathrm{M}\right)$ on membrane potential.

duced by procaine was less than that obtained by treatment with caffeine. Both procaine and caffeine depolarized the membrane but the ionic mechanism involved in this phenomenon differed, i.e., procaine increased the membrane resistance and suppressed the rectifying property of the membrane (CASTEELS et al., 1977a). Figure 3 shows the effects of procaine on membrane properties under displacement of the membrane potential by application of either inward or outward current. As shown in Fig. 3a, an absence of spike generation was not due to inactivation of the spike generating mechanism, since under conditioning

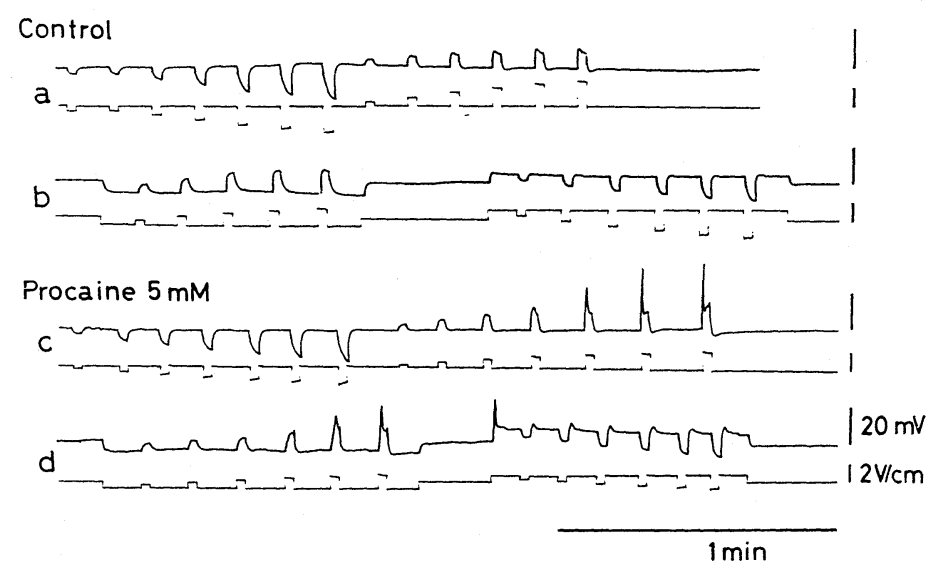

Fig. 3. Effects of various intensities of inward and outward current pulses on membrane properties at different membrane potentials. a and b; control, $\mathrm{c}$ and $\mathrm{d} ; 5 \mathrm{~mm}$ procaine. 
hyperpolarization of the membrane the spike was not evoked (Fig. 3b). When the concentration of procaine was increased more than $1 \mathrm{mM}$, the outward current pulse evoked a graded electrical response. The amplitude of the spike did not show the 'all or none' characteristic. When the spike showed maximum amplitude $(35 \mathrm{mV})$, the maximum rate of rise was only $3.1 \mathrm{~V} / \mathrm{sec}$, a value much lower than that obtained in spontaneously active visceral smooth muscles $(20 \mathrm{~V} / \mathrm{sec}$; KuriYAMA, 1970).

From the present and previous studies (ITo and KurIYAma, 1971; CASTEELS et al., 1977b), it is conclucled that both agents depolarized the membrane mainly due to either increase in ionic conductance by caffeine or decrease in ionic conductance of the membrane by procaine.

\section{Effects of caffeine and procaine on electrical and mechanical activities}

Figure 4 shows the effects of caffeine $(10 \mathrm{~mm})$ on the relationship between

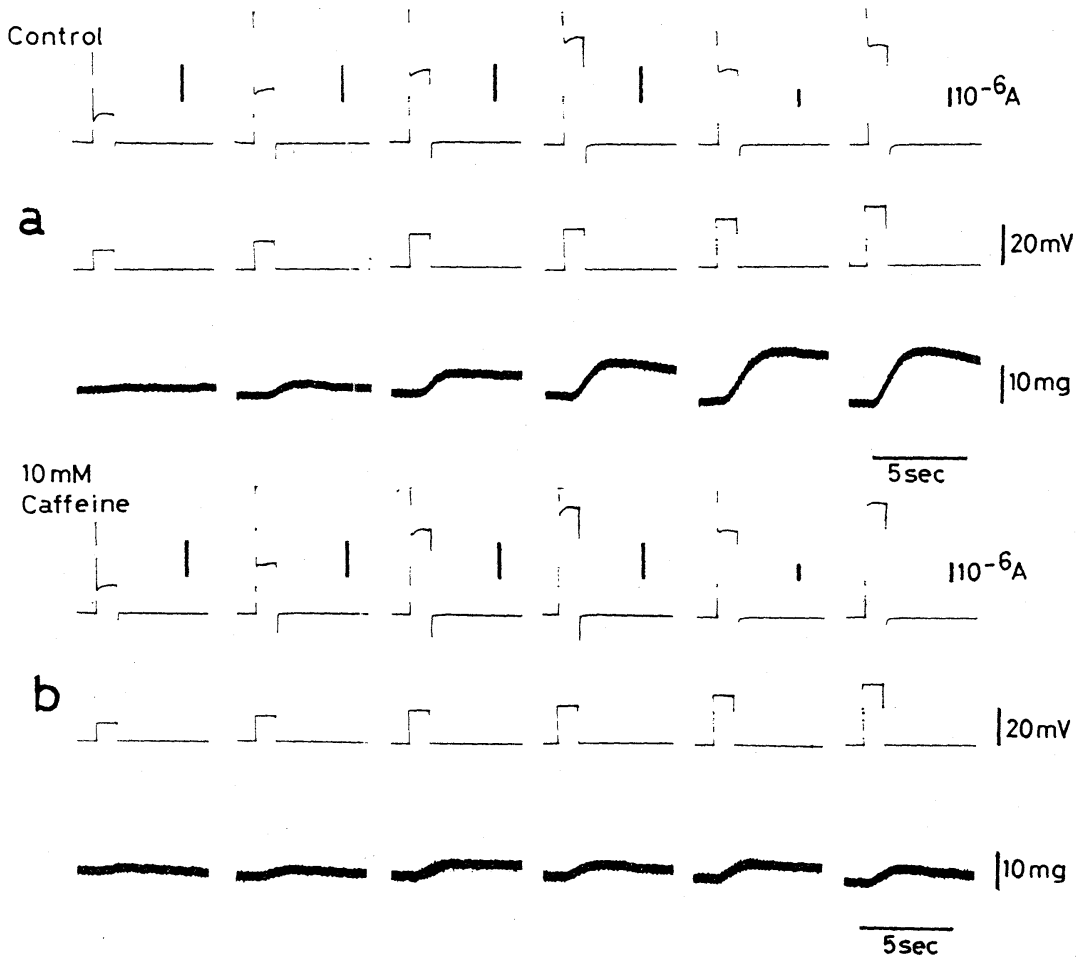

Fig. 4. Effects of caffeine $(10 \mathrm{~mm})$ on membrane responses induced by stepwise applied depolarization by voltage clamp procedures. $a$; control, $b$; in the presence of $10 \mathrm{~mm}$ caffeine. Top; current recording, middle; potential recording, bottom; mechanical response. Before and during application of caffeine, membrane potential was hold at the same level. 
depolarization and contraction. To measure ionic current, depolarization and contraction, voltage clamp procedures were adapted. The membrane potential ranged from $-43 \mathrm{mV}$ to $-36 \mathrm{mV}$. When the amplitudes of depolarization were increased stepwise, the amplitudes of contraction were enlarged proportionally. The minimum depolarization (threshold depolarization) to produce a contraction was about $5 \mathrm{mV}$. The depolarization-contraction relation curve was composed of two slopes, i.e., until the membrane was depolarized at about $10 \mathrm{mV}$, the tension development was slow; and when the depolarization exceeded more than 10 $\mathrm{mV}$, the tension rapidly developed until the depolarization reached about $30 \mathrm{mV}$. During the application of depolarization, no early inward current was recorded in Krebs solution. When the membrane was depolarized stepwise to a similar extent following priorapplication of caffeine $(10 \mathrm{~mm})$ as in the Krebs solution, the amplitude of contraction was much smaller than in the control, and the threshold depolarization to generate the contraction was also raised. Before and during application of caffeine, a holding potential was fixed at the same potential level by application of electrical current. The electrical current to produce the same amplitude of depolarization in the presence of caffeine required large amounts compared with the control, as expected from the increased ionic conductance of the membrane. Figure 5 shows the relationship between depolarization and
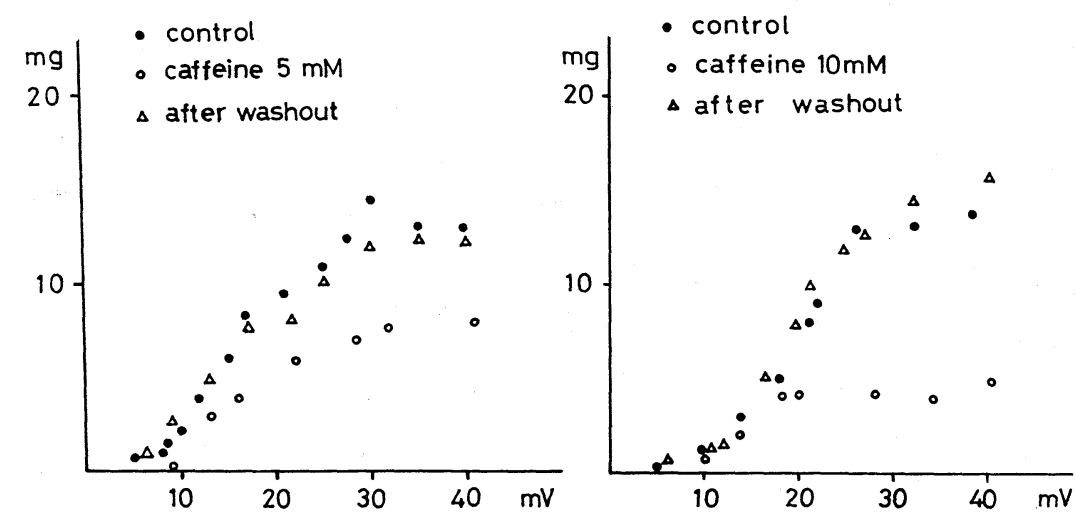

Fig. 5. Relationships between membrane potential and tension development before, during and after application of caffeine ( 5 and $10 \mathrm{~mm}$ ). Voltage clamp method employed. Holding potential was fixed at the same potential level before and during application of caffeine.

amplitude of contraction before, during and after application of caffeine ( 5 and $10 \mathrm{~mm})$. When the effects of caffeine were compared with the control, the depolarization of the membrane up to $15 \mathrm{mV}$ showed only slight suppression of contraction, and further depolarization of the membrane did not increase the contraction further.

When the effects of $10 \mathrm{~mm}$ procaine on the electrical and mechanical pro- 
perties were compared with those obtained in Krebs solution, the typical differences could be elucidated with those obtained in the presence of caffeine, i.e., i) mechanical responses were more suppressed, ii) early inward current was generated, and iii) amount of current to produce a certain depolarization was smaller. In spite of the generation of the early inward current, the mechanical response was markedly suppressed. During the experiment, the holding potential was fixed at the same membrane potential level by application of electrical current. On the other hand, when $5 \mathrm{~mm}$ procaine was applied to the tissue (Fig. 6), the contraction

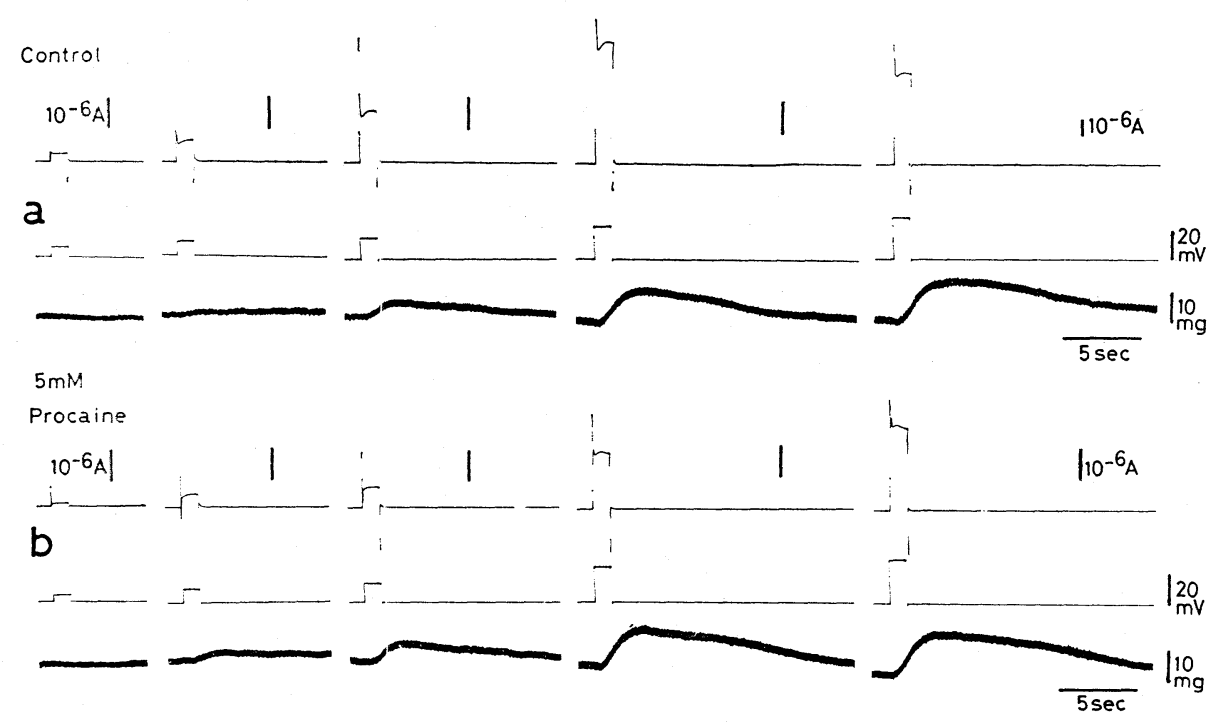

Fig. 6. Effect of stepwise depolarization of membrane on mechanical response before and during application of procaine $(5 \mathrm{~mm})$. a, control; b, procaine $5 \mathrm{~mm}$. The experimental procedures were the same with those described in Fig. 4.

recorded by the depolarization of the membrane showed nearly the same amplitude before and during application of procaine, yet an early inward current during depolarization was recorded. As shown in Fig. 7, when the relationships between the depolarization and contraction were plotted before, during, and after application of $10 \mathrm{~mm}$ procaine, the mechanical response was suppressed and the threshold depolarization to evoke contraction increased from $5 \mathrm{mV}$ to $18 \mathrm{mV}$, but by application of $5 \mathrm{~mm}$ procaine the amplitude of the mechanical response and the threshold depolarization were only slightly affected. These results obtained in the presence of procaine might suggest that it exerted dual action on the smooth muscle, i.e., procaine generated a spike thus increasing influx of $\mathrm{Ca}^{++}$during the active state and it also suppressed the activity of contractile protein either by suppression of the $\mathrm{Ca}^{++}$release from the stored sites or by suppression of contractile protein itself. 

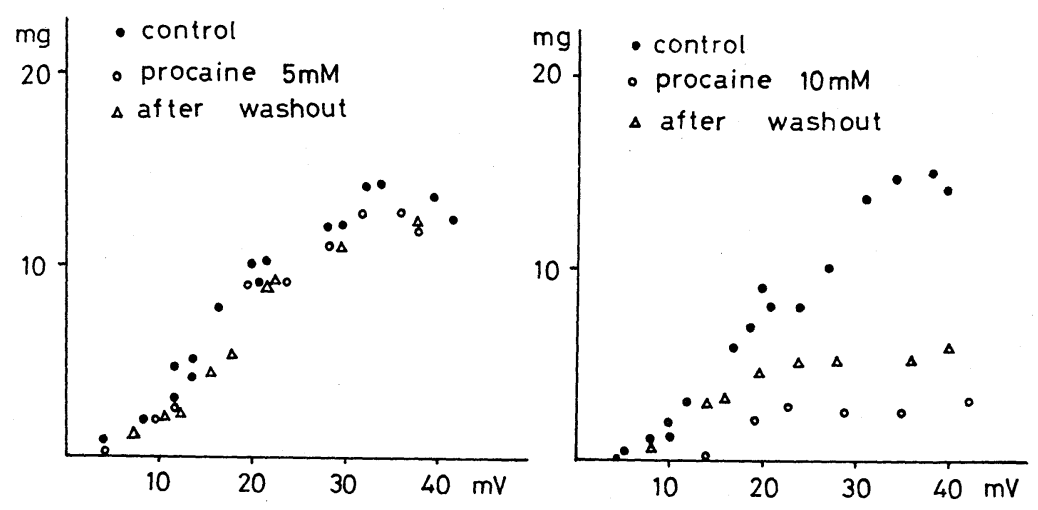

Fig. 7. Relationship between the membrane potential and tension development before, during and after treatment with procaine (5 and $10 \mathrm{~mm})$. Before and during application of procaine the membrane potential was held at the same level.

\section{Effects of procaine and caffeine on $K$-induced and chemically induced contracture}

To observe the effects of procaine and caffeine on $\mathrm{K}$ - or chemically induced contracture, $118 \mathrm{mM} \mathrm{K}^{+}$solution or noradrenaline $\left(5 \times 10^{-6} \mathrm{M}\right)$, acetylcholine $\left(10^{-6} \mathrm{M}\right)$ and prostaglandin $\mathrm{F}_{2 \alpha}\left(10^{-6} \mathrm{~g} / \mathrm{ml}\right)$ mixed solution (hereafter these mixed solution will be called chemicals, Iro et al., 1977) were used. Because the above individual three chemicals produced the contracture in Ca-free solution, they were applied simultaneously to release the stored $\mathrm{Ca}$ as many as possible (KITAMURA et al., 1976; CASTEELS et al., 1977b).

As shown in Fig. 8, caffeine (5 mM) transiently generated a small contracture then caused the tissue to relax. On the other hand, procaine $(5 \mathrm{~mm})$ gradually produced sustained tension. Caffeine $(5 \mathrm{~mm})$ suppressed both $\mathrm{K}$-induced and chemically induced contracture, while procaine ( $5 \mathrm{mM}$ ) suppressed K-induced contracture but little suppression was observed in the chemical-induced contracture. Moreover, the chemically induced contracture was superimposed on twitch contractions. As shown in Fig. 9, when the amplitudes of the chemically induced contracture in $\mathrm{Ca}$-free and $2.5 \mathrm{mM} \mathrm{Ca}^{++}$solutions were compared in the presence of either procaine $(5 \mathrm{mM})$ or caffeine $(5 \mathrm{~mm})$, both agents rapidly suppressed the chemical induced contracture in Ca-free $(0.1 \mathrm{~mm}$ EGTA) solution. The time to reach half amplitude of the maximum contracture was about $4 \mathrm{~min}$ in the presence of procaine or caffeine; this value was nearly one-fifth of the control value. When the effects of procaine and caffeine on chemically induced contracture in the presence of $2.5 \mathrm{mM} \mathrm{Ca}^{++}$were observed, the contraction transiently declined then slightly recovered in amplitude but the steady level after $60 \mathrm{~min}$ in caffeine solution was only 0.4 times the control amplitude. While in procaine solution the amplitude of contraction gradually declined and reached a steady level after $20 \mathrm{~min}$ at 0.8 times the control value. 
a

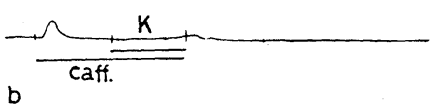

b
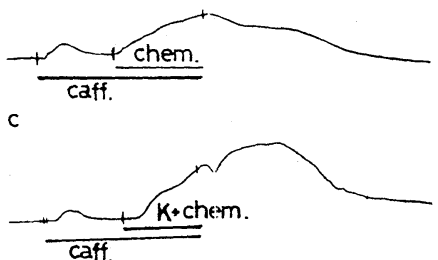

$d$
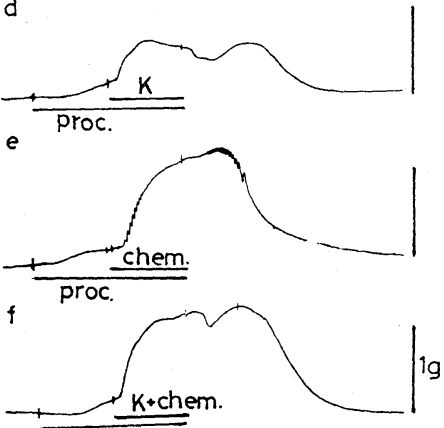

proc.

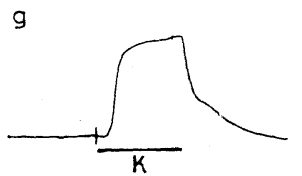

h

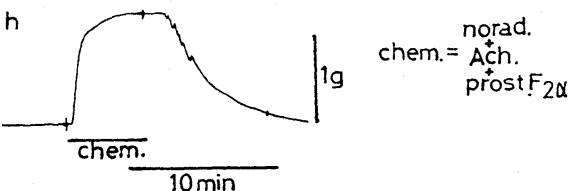

Fig. 8. Effects of caffeine $(5 \mathrm{~mm})$ and procaine $(5 \mathrm{~mm})$ on $\mathrm{K}$-induced and chemically induced contracture. $\mathrm{g}$, effects of $115 \mathrm{~mm} \mathrm{~K}$ solution in Krebs solution; h, effects of chemicals in Krebs solution; a-c, effects of $\mathrm{K}^{+}$, chemicals and $\mathrm{K}^{+}$with chemicals under pretreatment with caffeine; $d-f$, similar effects with a-c were observed under pretreatment with procaine.

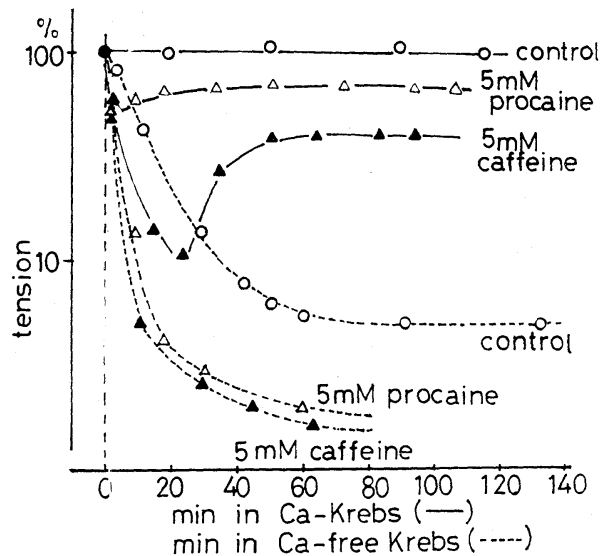

Fig. 9. Effects of procaine $(5 \mathrm{~mm})$ and caffeine $(5 \mathrm{~mm})$ on chemically induced contracture in presence or absence of $2.5 \mathrm{mM} \mathrm{Ca}^{++}$. Maximum amplitude of mechanical response in Krebs solution registered as $100 \%$ (logarithmic scale). Compositions of the chemical were $5 \times 10^{-6} \mathrm{M}$ noradrenaline, $10^{-6} \mathrm{M}$ acetylcholine and $10^{-6} \mathrm{~g} / \mathrm{ml}$ prostaglandin $\mathrm{F}_{2 \alpha}$.

KITAMURA et al. (1976) observed the differences and similarities of noradrenaline and prostaglandin $\mathrm{F}_{2 \alpha}\left(\mathrm{PGF}_{2 \alpha}\right)$ actions on the electrical and mechanical 
properties of smooth muscle cells of the pulmonary artery, i.e., both agents depolarized the membrane, increased ionic conductance of the membrane and produced contraction. However, under pretreatment with procaine, noradrenaline actions on the contractions were suppressed by $\mathrm{PGF}_{2 \alpha}$ actions were enhanced. In the present experiments, effects of noradrenaline and $\mathrm{PGF}_{2 \alpha}$, after pretreatment with either caffeine or procaine on the membrane properties were observed. Figure 10 shows the effects of noradrenaline $\left(5 \times 10^{-4} \mathrm{~mm}\right)$ and Fig. 11 shows the

\section{Rabbit Pulmonary Artery}

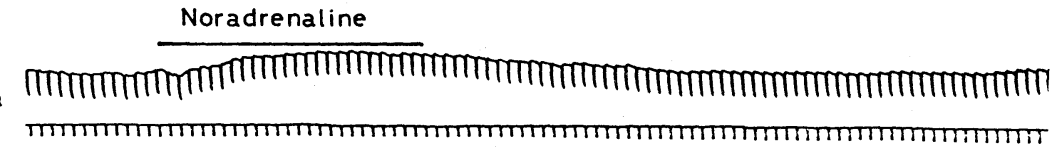

Procaine

b

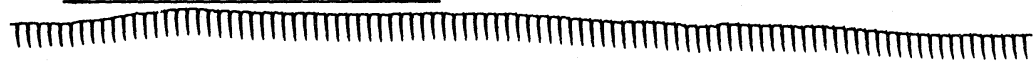

Caffeine

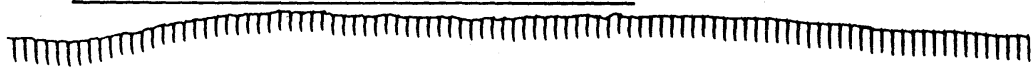

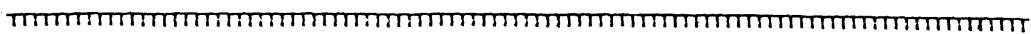

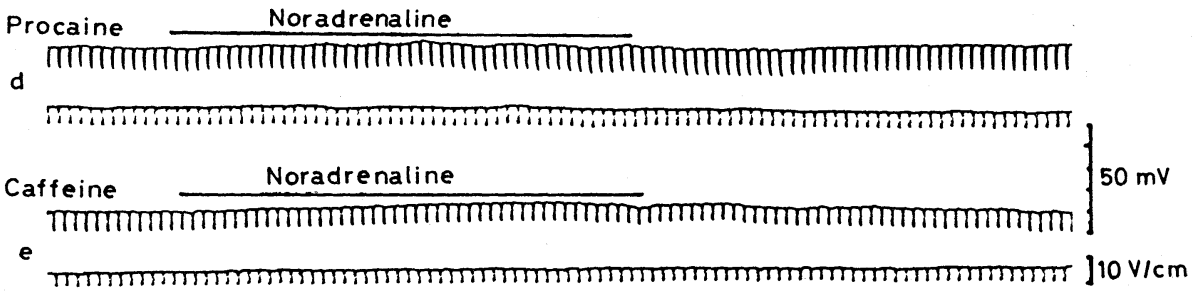

$\overline{\mathrm{Imin}}$

Fig. 10. Effects of noradrenaline $\left(5 \times 10^{-4} \mathrm{mM}\right)$, procaine $(5 \mathrm{mM})$ and caffeine $(5 \mathrm{mM})$ on electrotonic potentials produced by successively applied inward current pulses. a, effects of noradrenaline $\left(5 \times 10^{-4} \mathrm{mM}\right)$; $b$, effects of procaine $(5 \mathrm{~mm})$; c, effects of caffeine $(5 \mathrm{mM})$; d, effects of noradrenaline $\left(5 \times 10^{-4} \mathrm{mM}\right)$ under pretreatment with procaine $(5 \mathrm{mM})$; e, effects of noradrenaline $\left(5 \times 10^{-4} \mathrm{mM}\right)$ under pretreatment with caffeine $(5 \mathrm{~mm})$. Bottom; monitor of applied inward current. Inward current pulses (pulse duration; $1 \mathrm{sec})$ were applied every $10 \mathrm{sec}$.

effects of $\mathrm{PGF}_{2 \alpha}$ during application of either procaine $(5 \mathrm{~mm})$ or caffeine $(5 \mathrm{mM})$ on the membrane potential and electrotonic potential recorded by the microelectrode method. Following pretreatment with either procaine or caffeine, neither noradrenaline nor $\mathrm{PGF}_{2 \alpha}$ depolarized the membrane or increased the ionic conductance of the membrane. This means that actions of noradrenaline 


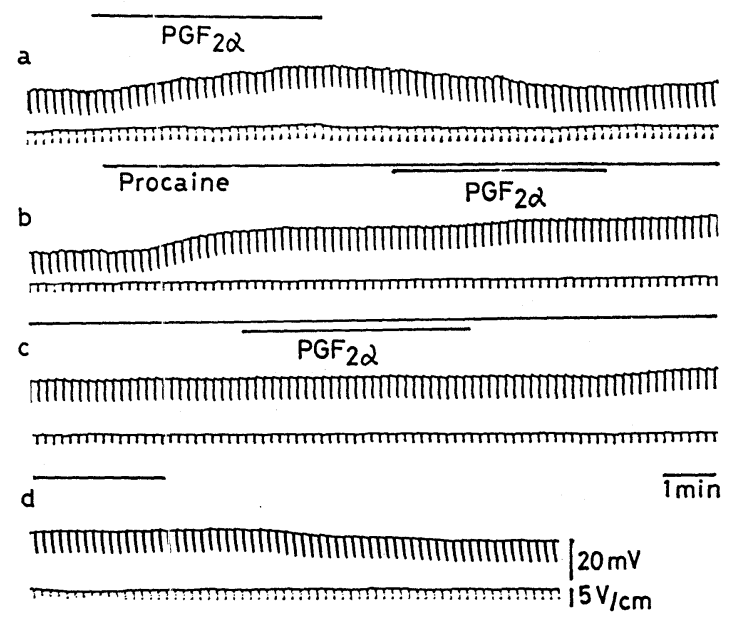

Fig. 11. Effects of prostaglandin $\mathrm{F}_{2 \alpha}\left(5 \times 10^{-7} \mathrm{~g} / \mathrm{ml}\right)$ on electrotonic potentials produced by successively applied inward current pulses before and during application of procaine $(5 \mathrm{~mm})$. a, control; b-c, effects of $\mathrm{PGF}_{2 \alpha}$ during application of procaine. Bottom; monitor of applied inward current. Inward current pulses (pulse duration; $1 \mathrm{sec}$ ) were applied every $10 \mathrm{sec}$.

and $\mathrm{PGF}_{2 \alpha}$ on the membrane were completely suppressed by pretreatment with procaine or caffeine, and therefore, the differences observed between these two agents on the mechanical activity might be caused by the difference in the Careleasing mechanism from the stored sites.

\section{DISCUSSION}

In the smooth muscle cells of the rabbit main pulmonary artery, caffeine depolarizes the membrane, modifies the ionic permeability and releases cellular $\mathrm{Ca}^{++}$in the same way as that observed by treatment with noradrenaline; and caffeine relaxes the tissue during noradrenaline stimulation (CASTEELS et al., 1977b; KITAMURA et al., 1976). On the other hand, procaine depolarizes the membrane accompanied by a small but significant decrease in the rate coefficient of the $\mathrm{K}$ efflux (CASTEELS et al., 1977b). Similar observations made on membrane using electrophysiological techniques in other visceral muscles have been reported (in taenia coli, Ito and KuriYAma, 1971; Bülbring and Kuriyama, 1973; ITO et al., 1973; in urinary bladder, KurIHARA, 1975; in tracheal muscle, SuzUKI et al., 1976). The present experiments confirmed the above observations, and differences in actions of both agents on the membrane and mechanical properties of muscle cells could be specified further: i) Critical concentration of caffeine to depolarize the membrane was much higher than that observed in the guinea pig alimentary canal (ITO and KuRIYAMA, 1971). Critical concentrations of procaine to depolarize the membrane and to generate a spike by outward 
current were roughly the same in order of magnitude as those obtained in the trachea and urinary bladder (SUzUKI et al., 1976; KuriHARA, 1975). ii) Both caffeine and procaine acted on the surface membrane as depolarizing agents but the ionic mechanism differed. This means that both agents act on the surface membrane with different ionic mechanisms. iii) Caffeine (1-10 mM) consistently reduced the mechanical response evoked by depolarization, but low concentration of procaine (1-5 mM) did not reduce the response due to spike generation. In this muscle, a spike was carried out by $\mathrm{Ca}$-inward current thus causing increase in free $\mathrm{Ca}^{++}$in the cell. Since depolarization induced contraction might be suppressed, the amplitude of mechanical response induced by $5 \mathrm{~mm}$ procaine remained the same before and during application. iv) Procaine and caffeine may not act competitively at the same locus in Ca-stored sites in the cell when governing release or uptake of $\mathrm{Ca}^{++}$since both agents suppressed $\mathrm{K}$-induced contracture in either the presence or absence of $\mathrm{Ca}^{++}$. Furthermore, the effects of noradrenaline and $\mathrm{PGF}_{2 \alpha}$ on the membrane were suppressed by pretreatment with these agents. Moreover, caffeine and procaine suppressed noradrenaline induced contraction, but caffeine suppressed and procaine accelerated the $\mathrm{PGF}_{2 \alpha}$ induced contraction. These observations therefore, suggest that the actions of noradrenaline and $\mathrm{PGF}_{2 \alpha}$ differ in the contractile mechanism.

It is known that procaine possesses local anesthetic action on many excitable cell membranes, especially on nerve fibers. These actions are referred to as stabilizing of the membrane, and during an active state of the membrane procaine suppresses $\mathrm{Na}$ and $\mathrm{K}$ activation mechanisms (ShANeS, 1958). BLAUSTEIN and Goldman (1966) reported that procaine action in nerve fibers was antagonized by increased $\mathrm{Ca}^{++}$concentrations. On the other hand, however, ÅRHEM and FrankenHAEUSER (1974) and NARAHASH et al. (1976) did not arrive at the same conclusion since their results did not suggest competitive actions at the same locus. These actions of procaine were quite different from those obtained in smooth muscle. In fact, in smooth muscles, procaine depolarized the membrane, suppressed the ionic conductance, and increased the excitability of the membrane.

Iто et al. (1977) reported that the mechanism releasing $\mathrm{Ca}^{++}$from stored sites in the pulmonary artery was more strongly affected by the chemical substance than by depolarization, and the depolarization induced contraction was mainly due to increase in $\mathrm{Ca}$ influx from the extracellular compartment. This means that caffeine and procaine affected both $\mathrm{Ca}$ influx and $\mathrm{Ca}$ releasing mechanisms which were activated by depolarization and chemical stimulation, respectively. These phenomena were quite different than those obtained from the striated muscle described by EBASHI (1976), i.e., caffeine and procaine act on the $\mathrm{Ca}$-induced $\mathrm{Ca}$ release mechanism, the former labilizing and the latter stabilizing the above mechanism.

The physiological roles of the Ca-induced $\mathrm{Ca}$ release mechanism in smooth muscle are not yet elucidated, however the microsomal fractions extracted from 
various smooth muscles are known to possess a $\mathrm{Ca}$ accumulating property (DEVINE et al., 1972; BATRA, 1973; CARSTEN, 1973; Hurwitz et al., 1973). Therefore, the microsomal fractions of smooth muscle might possess different properties than those obtained in skeletal muscle, thus suggesting that the internal and external membrane systems in this muscle differ from those of skeletal muscle.

Still, understanding of these drug actions on smooth muscle is unsatisfactory. CASTEELS et al. (1977b) reported that caffeine and noradrenaline increased efflux of $\mathrm{K}^{+}, \mathrm{Cl}^{-}$and $\mathrm{Ca}^{++}$, and presumable of $\mathrm{Na}^{+}$, yet the former suppressed while the latter increased tension development. On the other hand, procaine suppressed both efflux of $\mathrm{K}^{+}$and tension development but it did not suppress influx of $\mathrm{Ca}^{++}$ during active state of the membrane. Therefore, differences in mechanical response induced by procaine or caffeine might be due to the different response of the internal membrane structures compared with skeletal muscle. Further experiments will be required to understand the excitation-contraction mechanism in vascular smooth muscle in relation to the properties of the internal and external membrane structures with biochemical approaches.

\section{REFERENCES}

AвE, Y. and Tomita, T. (1968) Cable properties of smooth muscle. J. Physiol., 196: 87-100.

Anderson, N. C. (1969) Voltage-clamp studies on uterine smooth muscle. J. Gen. Physiol., 54: 145-165.

Århem, P. and Frankenhaeusiz, B. (1974) Local anesthetics: Effects on permeability properties of nodal membrane in myelinated nerve fibres from Xenopus. Potential clamp experiments. Acta Physiol. Scand., 91: 11-21.

BATrA, S. (1973) The role of mitochondrial calcium uptake in contraction and relaxation of the human myometrium. Biochem. Biophys. Acta, 305: 428-432.

Blaustein, M. P. and Goldmalv, D. E. (1966) Competitive action of calcium and procaine on lobster axon. A study of the mechanism of action of certain local anethetics. J. Gen. Physiol., 49: 1043-1063.

Bülbring, E., Brading, A. F., Jones, A., and Tomita, T. (1970) Smooth Muscle. Arnold, London.

Bülbring, E. and KurIYAma, E. (1963) Effects of changes in ionic environment on the action of acetylcholine and adrenaline on the smooth muscle cells of guinea pig taenia coli. $J$. Physiol., 166: 59-74.

Bülbring, E. and KuriYAMA, H. (1973) The action of catecholamines on guinea-pig taenia coli. Philos. Trans. R. Soc. London, Ser. B., 265: 115-121.

Bülbring, E. and Needham, D. M. (1973) A discussion on recent developments in vertebrate smooth muscle physiology. Philos. Trans. R. Soc. London., 265: 1-231.

Bülbring, E. and Shuba, M. F. (1976) Physiology of Smooth Muscle. Raven Press, New York, pp. 437.

Carsten, M. E. (1973) Prostaglandins and cellular calcium transport in the pregnant human uterus. Am. J. Obstet. Gynecol., 117: 824-832.

Casteels, R., Kitamura, K., Kuriyama, H., and Suzuki, H. (1977a) The membrane properties of the smooth muscle cells of the rabbit main pulmonary artery. J. Physiol., 271: 41-61.

Casteels, R., Kitamura, K., Kuriyama, H., and Suzuki, H. (1977b) Excitation-contraction coupling in the smooth muscle cells of the rabbit main pulmonary artery. J. Physiol., 271: 63-79. 
Devine, C. E., Somlyo, A. V., and Somlyo, A. P. (1972) Sarcoplasmic reticulum and excitation-contraction coupling in mammalian smooth muscles. J. Cell Biol., 52: 690-718.

Ebashi, S. (1976) Excitation-contraction coupling. Annu. Rev. Physiol., 38: 293-313.

ENDO, M. (1975) Conditions required for calcium-induced release of calcium from the sarcoplasmic reticulum. Proc. Jap. Acad., 51: 467-472.

Endo, M., TANaKa, M., and Ogawa, Y. (1970) Calcium induced release of calcium from the sarcoplasmic reticulum of skinned skeletal muscle fibres. Nature, 228: 34-36.

Ford, L. E. and Podolsky, R. J. (1972) Intracellular calcium movements in skinned muscle fibres. J. Physiol., 223: 21-33.

Goto, M., WADA, Y., and SAITo, M. (1974) Tension components and tension fall of the bullfrog atrial muscle during depolarization. Jap. J. Physiol., 24: 359-375.

Hurwitz, L., Fitzpatrick, D. F., Debbas, G., and Landon, E. J. (1973) Localization of calcium pump activity in smooth muscle. Science, 179: 384-386.

ITO, Y. and KuRIYAMA, H. (1971) Caffeine and excitation-contraction coupling in the guinea pig taenia coli. J. Gen. Physiol., 57: 448-463.

Ito, Y., KuRIYAma, H., and Suzuki, H. (1977) On the roles of calcium ion during potassium induced contracture in the smooth muscle cells of the rabbit main pulmonary artery. Jap. J. Physiol., in press.

Ito, Y., OsA, T., and KuriYAmA, H. (1973) Topical differences of caffeine action on the smooth muscle cells of the guinea pig alimentary canal. Jap. J. Physiol., 24: 217-232.

KeAting, W. R. (1975) Effect of local anesthetics on electrical activity and voltage dependent $\mathrm{K}$ permeability of arteries. Smooth muscle pharmacology and physiology. INSERM, 50: $177-182$.

Kitamura, K., Suzuki, H., and Kuriyama, H. (1976) Prostaglandin action on the main pulmonary artery an portal vein of the rabbit. Jap. J. Physiol., 26: 681-692.

KuriHARA, S. (1975) The effect of procaine on the mechanical and electrical activity of the smooth muscle cells of the guinea pig urinary bladder. Jap. J. Physiol., 25: 775-788.

Kuriyama, H. (1970) Effects of ions and drugs on the electrical activity of smooth muscle. In: Smooth Muscle, ed. by Bülbring, E., Brading, A., Jones, A., and Tomita, T. Edward Arnold, London, pp. 366-395.

Kuriyama, H., Osa, T., ITo, Y., and Suzuki, H. (1975) Excitation-contraction coupling mechanism in visceral smooth muscle. Adv. Biophys., 8: 115-190.

Narahashi, T., Frazier, D. T., and Takeno, K. (1976) Effects of calcium on the local anethetic suppression of ionic conductances in squid axon membranes. J. Pharmacol. Exp. Ther., 197: 426-438.

Oнbа, M., Sakamoto, Y., and TомiтA, T. (1975) The slow wave in the circular muscle of the guinea-pig stomach. J. Physiol., 253: 505-516.

Rougier, O., Vassort, G., Garnier, D., Gargouil, Y. M., and Coraboeuf, E. (1969) Existence and role of a slow inward current during the frog atrial action potential. Pfügers Arch., 308: 91-110.

Shanes, A. M. (1958) Electrochemical aspects of physiological and pharmacological action in excitable cells. Pharmacol. Rev., 10: 59-273.

Somlyo, A. P. and Somlyo, A. V. (1968) Vascular smooth muscle. 1. Normal structure, pathology, Biochemistry and Biophysics. Pharmacol. Rev., 20: 197-272.

Suzuki, H., Morita, K., and Kuriyama, H. (1976) Innervation and properties of the smooth muscle of the dog trachea. Jap. J. Physiol., 26: 303-320.

Weber, A. (1968) The mechanism of the action of caffeine on sarcoplasmic reticulum. J. Gen. Physiol., 52: 760-772.

WORCEL, M. and VASSOP.T, G. (1976) Smooth muscle pharmacology and physiology. INSERM: les éditions de l'institut national de la santé et de la recherche Médical. Paris, pp. 463. 